\title{
Rewards and Commitment in Social Development: Equiping Modern Muslim Communities with Knowledge on Islamic Work Ethics towards Better Living Conditions
}

\author{
Assoc. Prof Dr Shukri Ahmad
}

\author{
Dr. Mohamad Khadafi Hj Rofie
}

Dr. Ssuna Salim

Centre for General Studies, College of Arts and Sciences, Universiti Utara Malaysia

Doi:10.5901/mjss.2016.v7n1s1p395

\begin{abstract}
Rewards and commitment are two significant ingredients in any activity concerning the quality of work. Research in Islamic work ethics focuses on internal rewards to be gained in the Hereafter, and the extrinsic rewards such as success and wealth acquisition in business results. Commitment plays a significant role in the success of any person or organization based on jobs noble values. The committed workers will be able to ensure the success of any business effectively. Islam has outlined the principles of work ethics through the concept of rewards and commitment in society to render service to Allah and to the communities. This paper will discuss the concept of Islamic work ethics in terms of commitment and rewards and how useful these aspects are in equipping the current Muslim societies to contribute actively towards their better living conditions. The study uses a textual analysis methodology. The study is of the view that, the internal and external commitment and rewards will play a prominent role in rebuilding modern Muslim communities after having been seriously passive and lack commitment in carrying out their work thus lagging backward a in comparison to other communities. It is hoped that this paper will throw some light and analysis on Islamic work Ethics involving reward and commitment to this community whose ingredients and application will be of crucial benefit to the their work ethics.
\end{abstract}

Keywords: Islamic work ethics, commitment, rewards, Muslim communities, Hereafter

\section{Introduction}

Islam uses an Arabic term Amal or al-kasb to refer to work; considered to be a spiritual activity, including other forms of behaviour and economic activities. This term has been mentioned in the Quran 371 times in 86 chapters. According to Furnham (1997) the term work generally means any activity committed by parts of the body, with or without a will. Yusof al-Qaradawi (2001) on the other hand, defines the term work as a conscious human effort, either alone or in a group, to produce goods or provide services; a mechanism to reduce poverty; a key element in practice that help people perform tasks as a vicegerent on earth. Islam makes work mandatory for every individual in human life, in order to satisfy basic needs such as food, housing and clothing, as well as fulfilling individuals and society needs. It is interesting to note that there is no minimum specified requirement, but simplicity meeting these needs are a priority (Barjoyai Bardai, 2002). Unfortunately, most people consider acts related to religion as a charity, while anything related to daily life as a work (Mohd Nor Wan Daud, 1991). This is a misconception; obviously, anything that takes place in this life, for instance, sustanace, carryoing out any activity, death, good or bad conditions of life were determined by Allah SWT, as it is stated by the Prophet in his saying thus; Each person is placed in his mother's womb as a sperm (semen), then becames alaqah (clot) for 40 days, then mudghah (a piece of flesh) for 40 days then God sends an Angel to blown into him a spirit, and then God sends an Angel and instruuct him to write four things related to his provision, his life span and his good and bad deeds (Bukhari, chapter of al-Malaikah Zikr, Muslim, UMI). It is crucial, however, to note that if people have no freedom of choice to act on their own will, then, they will not be charged with the responsibility (taklif,) in this situation, they will neglect the fact that they will be held responsible for their own actions (Zainal, 2003).

\section{Work and Struggle}

According to the Islamic teaching, nobody is capable of knowing any provisions which have been determined by the Almighty Allah in terms of its type, shape, quality, quantity, difficult or easier to acquire. Hence, the role of striving, 
because sustenance requires struggle. It is unlikely that a person will get something he has not struggled for it. Humans are not charged with acts that are things that have been predestined for them (idtirari) because these will occur without a corresponding struggle. However, this is different from actions in which man is free to determine the course of his option actions (ikhtiyari); hire an individual gives the freedom to work, thus, he is held responsible for his actions (Ulwan, Abdullah Nasih, 1988).

Therefore the idea of a life without struggle is supported by those who are unjust, something against the Islamic teaching. Islam encourages its followers to always put trust in Allah the Almighty, which trust must be preceded by struggle through the freedom of choice (al-Ghazali, 1987). Human beings need to have carefully designed planning in their lives so that individuals or members of the public do not just sit and wait for the destiny to determine their fate.

\section{Work and Spiritual Aspect}

Islam is against all ideologies which do not encourage work and striving in this earthly life for sustenance. Consequently, Islam is against laziness which results in bagging and disturbing others which must be avoided by Muslims (al-Suyuti, 1954; Ibn Hajar, 1989). The Prophet said: He who bears string and carries firewood for selling for the pleasure of Allah, he is more dignified than asking from others whether his request is accepted or rejected. (Reported by al-Bukhari, n.d, Bab al-Zakah) This Hadith explains human dignity through work as demanded by Islam by giving the impression that one who searches for firewood for sale is nobler than the beggar. Islam does not encourage its adherents to base their survival on bagging; always hoping for assistance from others for those who are capable of working and struggling for themselves (Ibn Hajar, 1989). According to the Shafi'i school of thought the habbit of begging is prohibited for those capable of earning their living (Sayyed Qutb, 1981). Work should be done earnestly as it is a source of providing the basic necessities of life as well as stimulating the development of the surrounding communities, besides being a religious requirement and a way to get God's favours upon His servant (Ismail Raji al-Faruqi, 1998).

\section{Work and Values}

The main objective of the organization is to create a quality work management. Good quality work requires effort and struggle in order to develop and inculcate positive work attitudes in employees (Sharifah Hayaati, 2010). The creation of positive values requires the implementation of excellent work ethics among employees in order to achieve the objective of a given organization.. The inculcation of values and ethics in work management in Islam is the best because Islam is comprehensive; it's characterized by professionalism, dynamism and perfectness (Rozhan Othman, 1991).

In Islam all good and beneficial works are considered a form of worship. When an employee carries out his work in an ethical manner, then this symbolizes his obedience to the Almighty Allah, thus, fulfilling his requirement as a servant of God. The concept of work ethics and ethical values of Islam have been described in the Quran. Thus Allah says: Ye are the best community that hath been raised up for mankind. Ye enjoin right conduct and forbid indecency; and ye believe in Allah. And if the people of the Scripture (Jews and Christians) had believed it (as it should), it had been better for them. (But) some of them are believers; but most of them are evil-livers. (Surah al-Imran, 3: 110)

\section{Work and Ethics}

Work in Islamic management has strong ties with the values and ethics. Each value ethic that is in agreement with Islamic teachings will lead to excellence work that will result into the pleasure and blessings of the Almighty Allah; excellence in any work that is very closely related to that particular work ethic practiced (Zainal Yang, 2003). It is important to note that the measurement of work excellence in Islam is not based on skills and determination, but it caters for the personality development in view of Shari'a, however, this should begin from the top management level of the organization then executed in the executive and consequently implemented and appreciated by the subordinates. It is crucial to note that the concept of work ethics and value in Islam should be inculcated, and nurtured as a culture in the daily work (Ayub Osman, 1990). This concept If practiced routinely in daily tasks will create a culture of good quality work., which eventually will generate a systematic work culture with a defined procedure, rules and regulations easy to implement (Harold Koontz, 2001).

\section{Islamic Work Ethic}

Shukri and Razali (2001) are of the opinion that work ethics in Islam refers to a set of values of a belief system based on 
the Quran and the Sunnah in relation to the concept of work. Apparently, the Islamic work culture has multi-dimensional relationships with various aspects of life, including social, political and economic aspects. There are at least eight aspects related to attitudes and behaviours of employees towards work. Islamic work ethics are based on the Quran and alSunnah (Ahmad, 1976), and it demands that there must be a balance between the individual and society.

According to Sayyed Hussein Nasr (1989) Islamic work ethics must be based on al-Quran and al-Sunah as these two sources constitute many basic clearly stated principles of life, whereby some are straight forward, to understand while others require explanations, however, it is important to note that a perfect and a systematic work ethics in Islam must have its principles based on the main sources of the Quran and Hadith.

On the other hand Ali, A (2001) asserts that work ethics in Islam consist of several key principles such as justice, perseverance, responsibility and cooperation. These basic principles are interconnected with commitment and reward, they will produce excellent work as demanded by Islam. Work ethics in Islam, according to the Quran and al-Sunnah has close ties with commitment and reward, for al-Quran praises those who do their work diligently and struggle to earn a living earnestly. Each individual is promised a big reward for the work performed perfectly to satisfy the needs of their lives, even though it requires a struggle (Abeng, 1997).

Western scholars like Blood, (1969), Aldag and Brief, (1975), Putti (1989), Oliver, (1990) Jones, (1997) have carried out numerous studies on work ethics which mainly focussed on commitment and employee benefits. According to them, there is a significant relationship between work ethics, commitment and employee benefits. Interestingly, Abbas Ali (2008) affirms that empirical studies also show that the work ethics in Islam has a relationship with commitment and reward. Yuosef (2000) agrees with Abbas Ali (2008) and stresses that there exists a positive relationship between Islamic work ethics, commitment and reward.

Generally there are eight principles of work ethics that are found in al-Quran and Sunnah. They are; Taqwa (piety), Amal Soleh (right conduct), al-Birr (goodness), al-Qist (balance), Ihsan (charity), Mas'uliyyah (responsibility), Maaruf (righteous) and Itqan (assiduous).

It is apparent from the above mentioned principles that al-Quran and Hadith cover various aspects of knowledge, including the ethical aspect that can serve as a guide in the daily life of an individual. It can be concluded that the objective of work ethics principles in the Quran and Sunah is to achieve piety; the main principle that will lead to excellent work consequently leading to the pleasure of Almighty Allah. This same principle of piety will result into commitment and reward; two other aspects related to excellence in work, which is considered also to be the main focus of East and Western scholars.

\section{Commitment}

Abd. Aziz Yusof, (2008) defines commitment as individual accountability to his job or the organization which demonstrates his attitude based on values that are owned and created through serving the organization. Kamal Hassan, (1992) is of the view that assessment of commitment will be demonstrated by a person through his involvement in the occupation or organization, thus, confidence and belief about the purpose and work ethics and his organization will be higher, consequently, the worker will have the interest and ability to work hard in order for the organization to realize its goal, besides becoming among permanent workers.

On the other hand, al-Qaradawi, (1995) attests that it is the responsibility of Muslim workers to carry out their work excellently using a wide range of programs. Muslim workers also need to be aware that the realization of an ideal Islamic society and communities is a religious duty, this is because commitment to religion or doing something for the sake of Allah the Almighty cannot be compared to other commitments of a lesser value. (Ahmad Ibrahim, 1991). This is due to the fact that Islam is a religion that is not separated from from social, political, economic and other realities. Instead, it is a practical and a comprehensive religion (Nor Azzah, 2002). The realization of these ideals is considered a struggle in the way of Allah the Almighty as well a righteous conduct; the duty of every Muslim..

In addition to that, commitment is an agreement or a high consensus that is very effective for the group to perform a given job (Siti Nor Akhidah, 2006). Emphasizing this aspect will enhance the spirit of cooperation and understanding. This cooperation can be created at various stages and work processes. The atmosphere of cooperation will be established through which new ideas will be acquired and beneficial suggestions provided, as a result difficult job will be made easy, complicated problems solved, individual and group development achieved, organization development and services to the society and nation will be extended. (Md. Zahir, 2000). Meanwhile, teamwork is a process of cooperation in performing work and it is capable of yielding surprising results. All the factors related to work will be made more effective, consequently, improving work quality thus avoiding wastage.

Commitment accrues from the desire for the reward in this World and the Hereafter. This desire gives a boost to 
the employee to carry out their jobs. Islam emphasizes that the commitment to work be based on the eight (8) principles of Islamic work ethics. Determination and commitment in accordance with these principles will make one stronger in his servitude to Allah SWT.

According to Salleh al-Fahd (n.d), enthusiasm and commitment in work must be based on strong principles. Thus, the principles of Islamic work ethics are based on a strong foundation derived from the Quran and Hadith. It is apparent that commitment and determination to work will not be properly guided if not based on clear principles. Consequently, rewards alone cannot guarantee a continuous commitment. This is because the commitment and enthusiasm of the workers are more related to their attitudes rather than mere reward.

Therefore, work ethics principles based on al-Quran and Hadith fulfils human needs as servants of Allah SWT. The Value of Taqwa and Ihsan acts as a guide and control of the human heart, in the spirit of the work. The value of Amal Saleh, al-Birr, al-Qist, Masuliyah, Maarruf and Itqan drives an individual to execute the work diligently.

It should be observed that commitment and hard work require input and output. Input for work commitment relates to the confidence in the nature of work to be carried out. If one subscribes to the belief in Allah, surely he will hold to the principles and teachings derived from al-Quran, likewise, if one subscribes to a particular belief, then, he will carry out that work in accordance to that belief. On the other hand, the output of work, commitment can also be understood as a result of excellent work done to the maximum satisfaction of the employee. As a result, the commitment can be summed up as a feeling of satisfaction about their work, hence, becoming more focused and working harder. This clearly shows a strong relation that exists between commitment and reward accruing from employees as a result of practicing Islamic work ethics, whereby, a combination of the two aspects produces excellent work.

Work commitment is motivated by reward. Rewards in Islam are of two types; rewards in this world and rewards in the hereafter. To obtain both forms of rewards one must have devotion to God, which will create an intrinsic value that will stimulate actions which are a manifestation of the internal stimuli.

\section{Reward}

Azman Omar, (1997) is of the view that there are two forms of reward; internal (intrinsic) and external (extrinsic). The internal reward does not directly exist in the reward scheme such as duty, responsibility, power, position, recognition, awards and achievements. These are indirectly achieved through work and actions in a situation that occurs in the organization. Meanwhile, the extrinsic rewards include salary, allowances, bonuses, commissions, working conditions, company policies, technical assistance, supervision and safety of workers (Vroom, 1995). Hence, the rewards are divided into internal and external types earned by workers, resulting from their work (Shaffer, 1994), and also any payments and remuneration received by them on their services provided (Shailer, 1994).

Interestingly, from In Islamic point of view, rewards are more encompassing and more holistic including rewards in this world and the Hereafter. Rewards as viewed from the Islamic perspective require a balance and harmony without sidelining any one of them (al-Qardhawi, 2000). It is not fit for an individual to only focus on worldly benefits neglecting the Hereafter (Ibn Hajar, 1989). Allah Almighty says:

And of them there are who say "Our Lord, give us in this world that which is good and in the Hereafter that which is and, save us from the torment of the fire.. (Surah al-Baqarah, 2: 201)

\section{Conclusion}

The two important aspects of the work ethics of the remuneration and commitment, in addition to satisfaction act as the pillars that lead to success and excellence in work. These principles can be one of the crucial factors that will lead to the emancipation of Muslim societies from poverty, ignorance, backwardness and the injustices that have engulfed them for centuries. In addition to that, the reward emphasized by the Quran which focuses on earthly rewards and the Hereafter will act as an impetus in the liberation of Muslims to better living conditions. Thus, whatever the work, action, effort and development process must be established to seek rewards and pleasure of the Almighty Allah. This spirit of heavenly reward, will create a positive attitude and strength, which ultimately will provide tremendous inner strength to continue the efforts to bring change to contemporary Muslim communities

In addition to remuneration, commitment is another important aspect through which a change to Muslims today can be achieved. The Muslim communities need to be exposed to the concept of work ethics in Islam as embodied in this concept. Commitment refers to an ongoing effort to achieve the purpose, hence, an effort to change and improve life of Muslims require a commitment and active involvement of the entire Islamic community. It is the responsibility of all parties involved to have the feeling of commitment in order to make sure that Muslim struggle is based on strong and 
sounding religious commitment. Consequently, the success in changing Muslims from the backwardness, it has suffered from four centuries can effectively be achieved by cultivating in everybody involved in this struggle the values of work ethics in Islam.

\section{References}

Ab. Aziz Yusof \& Ahmad Bashir Aziz. (2008). Pengurusan perniagaan Islam, konsep isu dan pelaksanaan (Islamic business management, concept and implementation issues). Sintok: Publisher Universiti Utara Malaysia.

Abbas, 'Ali. (2001). Scaling an Islamic work ethic. The journal of social psychology. 572-583.

Ahmad Ibrahim Abu Sin. (1991). Pengurusan dalam Islam (Management in Islam) (Kuala Lumpur: Dewan Bahasa dan Pustaka.

Ahmad, K. (1976). Islam: Its meaning and message. Islamic Council of Europe. London.

Al-Bukhari, Muhammad bin Isma'il bin Ibrahim. (1996). Sahih al-Bukhari. Beirut: Dar al-Fikr.

Al-Ghazali, Abu Hamid Muhammad. (1987). Khuluq al-Muslim. Kaherah: Dar al-Rayyan Litturas.

Al-Qardhawi, Yusof. (1995). Dawr al-qiyam wa al-akhlaq fi al-iqtisad al-Islami. Kaherah: Maktabah Wahbah.

Al-Qardhawi, Yusof . (2001). Pengantar pengetahuan Islam (Introduction of Islam). (Mohammad Zaini Yahya, Trans.) Kuala Lumpur: al-Syabab Media.

Azman Che Omar. (2001). Pengurusan di Malaysia dari perspektif Islam. (Management in Malaysia from the perspective of Islam). Kuala Lumpur: Dewan Bahasa dan Pustaka.

Barjoyai Bardai. (2002). Prinsip dan kaedah pengurusan Islami: Lakaran suatu disiplin ilmu. Buku Wacana Pengurusan Islami (Islamic principles and management methods: Sketch of a discipline. Book Passage Islami Management): vol. 1. Kuala Lumpur: YPEIM.

Blood, M. R. (1969). Work value and job satisfaction. Journal of applied psychology. Vol. 53 No. 6. Pp. 456-9

Brief, A. P. \& Aldag, R. J. (1980). Antecedents of commitment among hospital nurses. Journal The sociology of work and occupations, 7 , $710-721$.

Furnham, A. (1997). Personality at work: The role of individual differences in the workplace. London \& New York: Routledge.

Ibn Hajar, Ahmad bin 'Ali bin Hajar al-Asqalani. (1989). Fath al-bari bi-sharh sahih al-Bukhari. Beirut: Dar al-Kutub al-'Ilmiyyah.

Ibn Kathir, Abi Fida Isma'il bin Kathir al-Quraisy al-Damsyiqi. (1994). Tafsir al-Quran al-'Azim. Beirut: Maktabah al-Asriyah.

Ismail Raji al-Faruqi. (1998). Al-Tawhid its implication for thought and life. Virginia, U.S.A: The International Institute of Islamic Thought.

Jones, H.B. Jr. (1997). The Protestant ethic; Waber model and the empirical literature. Human Relations. Vol. 50 No. 7. Pp. 757-778

Kamal Hassan. (1992). Muslim professionals facing the challenges of the 21st century: Beyond official code of ethics. Prosiding Seminar Kebangsaan Etika Profesional Amalan Etika Profesional. Universiti Teknologi Malaysia. Hotel Hilton, Kuala Lumpur.

Md. Zhahir Kechot. (2000). Ekonomi dan pengurusan organisasi (Economic and organizational management). Kuala Lumpur: Dewan Bahasa dan Pustaka.

Muslim, Abi Hussain Muslim Bin bin Hajaj Bin bin Muslim al-Qusyairi al-Naisaburi. (N.d). Sahih Muslim. Riyadh: Dar al-Salam..

Nor 'Azzah Kamri. (2002). Nilai dan etika dalam pengurusan Islam. Disertasi ljazah Sarjana Syariah (Values and ethics in the management of Islam. Dissertation Master of Shariah (unpublished). Jabatan Syariah dan Pengurusan, Akademi Islam. Universiti Malaya.

Oliver, R.L. (1990). Determinants and consequences of role conflict and ambiguity among retail sales managers. Journal of retailing. Vol. 53. Pp. $47-58$

Osman Ayub. (1990). Etika kerja dan professional Islam (Islamic work ethics and profesional). Kuala Lumpur: SABHA-FAMDEV.

Petri, H. L. (1991). Motivation, theory, research and applications. Belmont, California: Wordsworth Publishing Company.

Putti, J. M., Aryee, S. \& Ling, T. K. (1989). Work values and organizational commitment: A study in the Asian context. Human relations, 42, 275-288.

Rozhan Othman. (1991). Pengurusan personel dan perancangan guna tenaga. (Personnel management and manpower planning). Kuala Lumpur: Dewan Bahasa dan Pustaka.

Sayyed Hussein Nasr. (1989). Islamic work ethics, traditional Islam in the modern world. (Nasir Muhamad, Trans.), Kuala Lumpur: Nurin Enterprise.

Sayyid Qutb. (1981). Petunjuk sepanjang jalan. (Milestones). (A. Rahman Zainuddin, Trans.) T.tp.: Polygraphic Press.

Shaffer, D. R. (1994). Social \& personality development. California: Brooks/Cole Publishing.

Shailer, G. (1994). Capitalists and entrepreneurs in owner-managed firms. International Small Business Journal. 12(3). Pp 33-41.

Shukri Ahmad \& Razali Mat Zin. (2001). Adab dan etika kerja dalam organisasi (Adab and work ethic in the organization). Sintok: Universiti Utara Malaysia.

Siti Nor Akidah Samsudin. (2006). Hubungan etika kerja Islam dan komitmen organisasi satu kajian di kalangan kakitangan akademik Kolej Matrikulasi Arau, Perlis. Dissertation (unpublished). Universiti Utara Malaysia.

Suyuti, Jamaluddin 'Abd Rahman. (1954), ). Al-jami' al-saghir fi al-ahadith al-bashir wa al-nadhir, jil. 1. Qaherah: Dar al-Kutub al'ilmiyyah.

Syarifah Hayaati Syed Ismail. (2010). Etika penjawat awam dari perspektif Islam (Civil service ethics from an Islamic perspective). Kuala Lumpur: Dewan Bahasa dan Pustaka.

Ulwan, Abdullah Nashih (1988) Masalah taqdir (Problems of taqdir), Publication And Distribution Area, Kuala Lumpur: Thinkers Library.

Vroom, V. H. (1995). Work and motivation. C.1. San Francisco: Jossey-Bass.

Wan Mohd Nor Wan Daud (1991). Penjelasan budaya ilmu (Explanations culture of knowledge). Kuala Lumpur: Dewan Bahasa dan 
Pustaka.

Yousef, D. A. (1999). The Islamic work ethic as a mediator of the relationship between locus of control, role conflict and role ambiguity: A study in an Islamic country setting. Journal of managerial psychology, 283-302.

Zainal Yang. (2003, Jan). Nilai, etika dan budaya kerja dalam pentadbiran sektor awam di Malaysia dari perspektif Islam (Values, ethics and work culture in the administration of the public sector in Malaysia from the perspective of Islam). Jurnal pengurusan awam, Jilid 2, Bil 1. Jabatan Perkhidmatan Awam Malaysia. 